\title{
Bisphenol A effects on gene expression in adipocytes from children: association with metabolic disorders
}

\author{
Ciro Menale ${ }^{1,2,+}$, Maria Teresa Piccolo ${ }^{2,3, \ddagger}$, Grazia Cirillo4, Raffaele A Calogero $^{5}$, \\ Alfonso Papparella ${ }^{4}$, Luigi Mita ${ }^{2,6}$, Emanuele Miraglia Del Giudice ${ }^{4}$, Nadia Diano, ${ }^{1,2}$ \\ Stefania Crispi ${ }^{2,3, *}$ and Damiano Gustavo Mita ${ }^{2,6, *}$ \\ 'Department of Experimental Medicine, Second University of Naples, Via S. Maria di Costantinopoli 16, \\ 80138 Naples, Italy \\ ${ }^{2}$ National Laboratory of Endocrine Disruptors, INBB, Via P. Castellino 111, 80131 Naples, Italy \\ ${ }^{3}$ Gene Expression and Molecular Genetics Laboratory, IBBR - CNR, UOS Napoli Via P. Castellino 111, \\ 80131 Naples, Italy \\ ${ }^{4}$ Department of Woman, Child and General and Specialized Surgery, Second University of Naples, \\ Via Luigi De Crecchio 4, 80138 Naples, Italy \\ ${ }^{5}$ Bioinformatics and Genomics Unit, MBC Molecular Biotechnology Center, University of Turin, Via Nizza 52, \\ 10126 Turin, Italy \\ ${ }^{6}$ Biophysics Laboratory, IGB - CNR, Via P. Castellino 111, 80131 Naples, Italy \\ *(S Crispi and D G Mita contributed equally as co-last authors) \\ ${ }^{\dagger} \mathrm{C}$ Menale is now at IRGB - CNR UOS Milano c/o Humanitas Clinical Institute Research Center, \\ Via Manzoni 113, 20089 Rozzano, Milano, Italy \\ ${ }^{\mp} \mathrm{M}$ T Piccolo is now at Department of Environmental, Biological and Pharmaceutical Sciences and \\ Technologies, Second University of Naples, Via Vivaldi 43, 81100 Caserta, Italy
}

Correspondence

should be addressed

to $S$ Crispi

Email

stefania.crispi@ibbr.cnr.it

\begin{abstract}
Bisphenol A (BPA) is a xenobiotic endocrine-disrupting chemical. In vitro and in vivo studies have indicated that BPA alters endocrine-metabolic pathways in adipose tissue, which increases the risk of metabolic disorders and obesity. BPA can affect adipose tissue and increase fat cell numbers or sizes by regulating the expression of the genes that are directly involved in metabolic homeostasis and obesity. Several studies performed in animal models have accounted for an obesogen role of BPA, but its effects on human adipocytes especially in children - have been poorly investigated. The aim of this study is to understand the molecular mechanisms by which environmentally relevant doses of BPA can interfere with the canonical endocrine function that regulates metabolism in mature human adipocytes from prepubertal, non-obese children. BPA can act as an estrogen agonist or antagonist depending on the physiological context. To identify the molecular signatures associated with metabolism, transcriptional modifications of mature adipocytes from prepubertal children exposed to estrogen were evaluated by means of microarray analysis. The analysis of deregulated genes associated with metabolic disorders allowed us to identify a small group of genes that are expressed in an opposite manner from that of adipocytes treated with BPA. In particular, we found that BPA increases the expression of pro-inflammatory cytokines and the expression of FABP4 and CD36, two genes involved in lipid metabolism. In addition, BPA decreases the expression of PCSK1, a gene involved in insulin production. These results indicate that exposure to BPA may be an important
\end{abstract}


risk factor for developing metabolic disorders that are involved in childhood metabolism dysregulation.

\section{Introduction}

Bisphenol A (BPA) is the key monomer in the production of the polycarbonate and epoxy resins the are used for many food containers, such as cans or bottles for children (Halden 2010). BPA belongs to the class of endocrine disruptor chemicals (EDCs) that alter the functions of the endocrine system by competing with endogenous hormones. For humans, the main exposure to BPA occurs through the diet, with the intake of contaminated food and drinking water (Kang et al. 2006). BPA intake is higher and more dangerous in infants and children, and it can lead to the onset of several diseases, such as cancer, endometriosis, birth defects, and developmental and neuronal disorders (Rochester 2013, Delclos et al. 2014). BPA intake has also been associated with obesity and metabolic disorders (Rochester 2013, Lakind et al. 2014), specifically in children (Trasande et al. 2012, Lee et al. 2013, Nicolucci et al. 2013).

BPA is known to have estrogen-like properties, but some evidence has also shown that at low environmentally relevant doses, it can act as an estrogen antagonist by exerting an opposite effect, which suggests that BPA could act also through non-classical ER pathways (Li et al. 2012, Boucher et al. 2014).

In vivo and in vitro studies have confirmed that BPA exerts its disrupting effects on the classical nuclear receptors estrogen receptors alpha and beta (ER $\alpha$ and $\mathrm{ER} \beta)$, non-classical membrane estrogen receptor (ncmER), estrogen-related receptor gamma (ERR $\gamma)$, G proteincoupled receptor 30 (GPR30), and the aryl hydrocarbon receptor (AhR) (Hugo et al. 2008, Alonso-Magdalena et al. 2012). Through these interactions, BPA is thought to be involved in the onset of metabolic dysfunction. Given the lack of data in human subjects, more studies on molecular effects are needed in order to shed light on any association BPA may have with metabolic diseases, particularly in childhood obesity.

Currently, a large amount of attention has been paid to analyzing the BPA disrupting action in modulating endocrine functions of human adipose tissue. A recent study (Valentino et al. 2013) demonstrated a reduced insulin-stimulated tyrosine phosphorylation of insulin receptors in adult adipocytes treated with BPA and a consistent reduction of insulin downstream signaling. Another study (Wang et al. 2013) reported that environmentally relevant BPA concentrations in adipocytes from children increase the expression and the enzymatic activity of 11ß-hydroxysteroid dehydrogenase type 1 . This is a key enzyme in adipocyte differentiation and lipid synthesis. These results support the hypothesis that BPA could stimulate preadipocyte differentiation and adipogenesis and thus promote obesity in childhood.

Moreover, molecular studies have demonstrated that a large number of genes that are modulated by BPA induce negative health effects (Singh \& Li 2012). Specifically, BPA exposure during adipocyte differentiation affects gene expression and subsequently modulates adipose tissue functions. Examples include PPAR, C/EBP, LPL, GLUT4, CYP19, GPAT and DGAT, and Leptin (OB) (Vom Saal et al. 2012, Boucher et al. 2014, Ohlstein et al. 2014). BPA also increases lipoprotein lipase gene expression and the corresponding enzymatic activity that leads to triacylglycerol accumulation (Masuno et al. 2002). BPA has also been found to increase glucose transporter GLUT4 levels and thus to alter glucose uptake (Masuno et al. 2002, Sakurai et al. 2004). All of these aspects indicate that BPA exposure, by affecting gene expression, directly regulates adipocyte function and metabolism homeostasis.

In this paper, we describe the role of BPA in modulating canonical endocrine function, which regulates metabolism during childhood. We used differentiated mature adipocytes obtained from non-obese children to evaluate if environmentally relevant doses of BPA interfere with estrogen function in metabolism.

Genes associated with metabolism and those modulated by estrogen in adipocytes were selected by means of transcriptional analysis. Subsequently, the gene expression and physiological outcomes were further analyzed following BPA treatment.

The results indicated that environmentally relevant BPA doses induce changes in gene expression that are likely to affect their activity. Deregulated genes are potentially involved in metabolic disorders through the possible impairment of pancreatic functions.

Published by Bioscientifica Ltd. 


\section{Materials and methods}

\section{Chemicals and reagents}

Culture media, fetal bovine serum (FBS), penicillin, streptomycin, and L-glutamine were obtained from Euroclone (Milan, Italy). BPA, $17 \beta$ estradiol $\left(\mathrm{E}_{2}\right)$, collagenase type 1 , human insulin, recombinant human epidermal growth factor (rEGF), and oil red $\mathrm{O}(\mathrm{ORO})$ powder were purchased from Sigma-Aldrich. Trizol reagent and a Human Interleukin 1 Beta (IL1B) ELISA kit were obtained from Invitrogen Life Technologies. High-Capacity cDNA Reverse Transcription kit was purchased from Applied Biosystems. A GeneChip Human Gene 1.0 ST array was obtained from Affymetrix (Santa Clara, CA, USA). IL18 and CCL20 ELISA kits and a Triglyceride Quantification kit were obtained from Abcam (Cambridge, UK). A Human Insulin ELISA kit was purchased from Millipore (St. Charles, MO, USA).

\section{Patients and cell culture}

This study was approved by the ethical committee of the Second University of Naples. Informed consent was obtained by the parents and, where appropriate, by the children involved. All of the patients underwent orchidopexy surgery. For all of the samples, subcutaneous adipose tissue was collected from the inguinal area, which is a natural deposit of adipose tissue. A total of eight preadipocyte samples were in vitro differentiated in mature adipocytes: five samples were used for microarray analysis, and all of them were used for the subsequent biological validations (Table 1).

Human preadipocytes and differentiated mature adipocytes were cultured in phenol red free DMEM supplemented with $10 \%(\mathrm{v} / \mathrm{v}) \mathrm{FBS}, 100 \mathrm{U} / \mathrm{ml}$ penicillin, $100 \mu \mathrm{g} / \mathrm{ml}$ streptomycin, and $1 \mathrm{mM}$ L-glutamine. Preadipocytes were grown with $10 \mathrm{ng} / \mathrm{ml} \mathrm{rEGF}$. Subcutaneous adipose tissue fragments were obtained from eight nonobese children within $30 \mathrm{~min}$ after starting elective surgery. Adipose tissues were washed in culture medium for $1 \mathrm{~h}$ at $37^{\circ} \mathrm{C}$ and then digested using $1 \mathrm{mg} / \mathrm{ml}$ collagenase type 1 for $60 \mathrm{~min}$ at $37^{\circ} \mathrm{C}$. Dissociated tissue was pelleted at $1200 \mathrm{~g}$ for $10 \mathrm{~min}$, and the stromal-vascular cells and preadipocytes were resuspended in $160 \mathrm{mM}$ $\mathrm{NH}_{4} \mathrm{Cl}$ to remove erythrocytes. Cells were filtered (through $100 \mu \mathrm{m}$ nylon mesh), and the purified preadipocytes were seeded in $60 \mathrm{~mm}$ cell culture dishes. These cells were differentiated at passage IV. Differentiation into adipocytes was induced as previously described (Masuno et al. 2005). Adipocytes were cultured in medium supplemented with $10 \mu \mathrm{g} / \mathrm{ml}$ insulin. BPA treatments were done $24 \mathrm{~h}$ after the differentiation and culturing of adipocytes without insulin. Insulin was removed from the medium to avoid any effects of insulin stimuli on the gene expression.

Human pancreatic cell line PANC-1 was purchased from ATCC (http://www.atcc.org) and cultured in highglucose DMEM supplemented with 10\% FBS, $100 \mathrm{U} / \mathrm{ml}$ penicillin, and $100 \mu \mathrm{g} / \mathrm{ml}$ streptomycin. PANC-1 cells were cultured in high-glucose medium $(4.5 \mathrm{~g} / \mathrm{l})$ to stimulate insulin secretion. Cells were expanded up to passage $\mathrm{X}$ before use.

Cells were grown in a humidified atmosphere containing $5 \% \mathrm{CO}_{2}$ at $37^{\circ} \mathrm{C}$. Cells that had been treated with vehicle only $-0.1 \%(\mathrm{v} / \mathrm{v})$ ethanol - were used as the control.

Experiments were performed in triplicate for each sample.

\section{Cell treatments}

Mature adipocytes and PANC-1 human pancreatic cells were treated for $24 \mathrm{~h}$ with different BPA concentrations $(1,10$, and $100 \mathrm{nM})$ and/or $\mathrm{E}_{2}(1 \mathrm{nM})$ that were formed by diluting $100 \%$ ethanol stock solutions starting from 1,10 ,

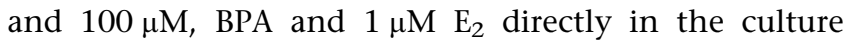
medium.

Table 1 Clinical sample characteristics

\begin{tabular}{|c|c|c|c|c|c|c|}
\hline Case no. & Age & Surgery & BMI & Array & qPCR & $\begin{array}{l}\text { Biological } \\
\text { validation }\end{array}$ \\
\hline 1 & 7 & Orchidopexy & 19 & & $X$ & $X$ \\
\hline 2 & 10 & Orchidopexy & 20 & $X$ & $x$ & $\mathrm{X}$ \\
\hline 3 & 8 & Orchidopexy & 19 & $X$ & $X$ & $X$ \\
\hline 4 & 8 & Orchidopexy & 20 & $X$ & $X$ & $X$ \\
\hline 5 & 9 & Orchidopexy & 21 & & $x$ & $X$ \\
\hline 6 & 9 & Orchidopexy & 20 & $x$ & $X$ & $X$ \\
\hline 7 & 8 & Orchidopexy & 20 & $X$ & $X$ & $X$ \\
\hline 8 & 10 & Orchidopexy & 19 & & $X$ & $X$ \\
\hline
\end{tabular}

http://jme.endocrinology-journals.org DOI: 10.1530/JME-14-0282
(C) 2015 Society for Endocrinology Printed in Great Britain
Published by Bioscientifica Ltd. 


\section{GeneChip array sample preparation and data analysis}

Microarray analysis was performed on in vitro-differentiated adipocytes of five non-obese children. In order to identify the estrogen transcriptional modifications, cells were treated for $24 \mathrm{~h}$ with $1 \mathrm{nM} \mathrm{E}_{2}$. Cells that had been treated with vehicle only were used as the control. Total RNA was extracted using Trizol reagent. Biotinylated cRNA target preparation and target hybridization were performed according to Affymetrix instructions. Experiments were performed using GeneChip Human Gene 1.0 ST arrays. All of the hybridizations, washing, staining, and scanning procedures were done using a GeneChip station (FS 450, Scanner 3000, Affymetrix), according to the manufacturer's instructions. Laser scanning generated CEL files.

Two prototypic situations - untreated and $\mathrm{E}_{2}$-treated cells - were analyzed to generate background-normalized image data. Data were analyzed using a ChannelGUI Bioconductor package. Gene-level calculations were performed by Robust Multichip Average, and normalization was achieved by quantile sketch, as previously described (Crispi 2013). To assess differential expression at the genelevel, an empirical Bayes method (Smyth 2004) together with a false discovery rate (FDR) correction of the $P$ value (Westfall \& Young 1993) were used. Differentially expressed genes were generated using an FDR of $\leq 0.05$ and an absolute $\log _{2}$-(fold-change) threshold of 1 . Microarray data were deposited in the Gene Expression Omnibus database (GEO accession no. GSE58516).

Deregulated genes were functionally classified through an IPA Core Analysis (IPA 7.0, Ingenuity Systems, Redwood City, CA, USA). IPA associates molecules under analysis with known biological functions and diseases. The link between a category and its associated molecules is defined by a $P$ value. In general, the more molecules that are involved, the more likely it is that the association is not a result of random chance, and thus the more significant the $P$ value.

\section{Quantitative RT-PCR analysis}

Total RNA (200 ng) from each adipocyte sample that had been untreated or treated with BPA or $\mathrm{E}_{2}$ was converted to cDNA using a High-Capacity cDNA Reverse Transcription kit under the conditions described by the supplier. Gene specific primers for the selected genes (Table 2) were designed at exon-exon junction using Primer Express 2.0 software (Applied Biosystems). Glyceraldehyde 3-phosphate dehydrogenase (GAPDH) was used as an internal control. The entire procedure for
Table 2 Genes amplified by RT-PCR and sequences of the primers used for their amplification

\begin{tabular}{|c|c|c|}
\hline Gene & & Primer sequence \\
\hline ESR1 & $\begin{array}{l}\text { Forward } \\
\text { Reverse }\end{array}$ & $\begin{array}{l}\text { GATGAAAGGTGGGATACGAAAAGA } \\
\text { CTCTGGCGCTTGTGTTTCAA }\end{array}$ \\
\hline ESR2 & $\begin{array}{l}\text { Forward } \\
\text { Reverse }\end{array}$ & $\begin{array}{l}\text { AAGAAGATTCCCGGCTTTGTG } \\
\text { AGCTCAGCCTGTTCG }\end{array}$ \\
\hline ESRRG & $\begin{array}{l}\text { Forward } \\
\text { Reverse }\end{array}$ & $\begin{array}{l}\text { GCCAGCCAAAAAGCCATATAAC } \\
\text { GGCATAGATCTTCTCCGGTTCA }\end{array}$ \\
\hline GPER & $\begin{array}{l}\text { Forward } \\
\text { Reverse }\end{array}$ & $\begin{array}{l}\text { ACGAGACTGTGAAATCCGCAACCA } \\
\text { ATCAGGCTGGAGGTGCACTTGGAA }\end{array}$ \\
\hline $\begin{array}{r}\text { Leptin } \\
(O B)\end{array}$ & $\begin{array}{l}\text { Forward } \\
\text { Reverse }\end{array}$ & $\begin{array}{l}\text { TCACCAGGATCAATGACATTTCA } \\
\text { CCAAACCGGTGACTTTCTGTTT }\end{array}$ \\
\hline FABP4 & $\begin{array}{l}\text { Forward } \\
\text { Reverse }\end{array}$ & $\begin{array}{l}\text { TTGACGAAGTCACTGCAGATGA } \\
\text { CAGGACACCCCCATCTAAGGT }\end{array}$ \\
\hline$I L 1 B$ & $\begin{array}{l}\text { Forward } \\
\text { Reverse }\end{array}$ & $\begin{array}{l}\text { CTGAGCTCGCCAGTGAAATG } \\
\text { TCAGCTTCAAAGAACAAGTCATCCT }\end{array}$ \\
\hline IL8 & $\begin{array}{l}\text { Forward } \\
\text { Reverse }\end{array}$ & $\begin{array}{l}\text { GAGTGATTGAGAGTGGACCACACT } \\
\text { AGAGCTCTCTTCCATCAGAAAGCT }\end{array}$ \\
\hline IL18 & $\begin{array}{l}\text { Forward } \\
\text { Reverse }\end{array}$ & $\begin{array}{l}\text { GCTGAACCAGTAGAAGACAATTGC } \\
\text { AGCTTGCCAAAGTAATCTGATTCC }\end{array}$ \\
\hline CCL20 & $\begin{array}{l}\text { Forward } \\
\text { Reverse }\end{array}$ & $\begin{array}{l}\text { CCACCTCTGCGGCGAAT } \\
\text { CTGTGTATCCAAGACAGCAGTCAA }\end{array}$ \\
\hline $\mathrm{CCl} 13$ & $\begin{array}{l}\text { Forward } \\
\text { Reverse }\end{array}$ & $\begin{array}{l}\text { GCAGAGGCTGAAGAGCTATGTGA } \\
\text { CTCCTTGCCCAGTTTGGTTCT }\end{array}$ \\
\hline CD36 & $\begin{array}{l}\text { Forward } \\
\text { Reverse }\end{array}$ & $\begin{array}{l}\text { TGAAGAAGAACATAGGACATACTTGGA } \\
\text { TGCAGCCGTTTTGCAAATT }\end{array}$ \\
\hline PCSK & $\begin{array}{l}\text { Forward } \\
\text { Reverse }\end{array}$ & $\begin{array}{l}\text { TCTTCAATGATCCCATGTGGAA } \\
\text { GCAGGGCTGCCGTCATC }\end{array}$ \\
\hline
\end{tabular}

quantitative RT-PCR (qRT-PCR) analysis - including primer design, reactions, amplicon specificity, and determination of gene target expression levels - was performed as previously described (Crispi et al. 2009).

\section{Lipid area and triglyceride content}

Cytoplasmic lipid accumulation was determined by ORO staining, as previously described (Kuri-Harcuch \& Green 1978). Cells fixed with $10 \%$ (v/v) formalin in PBS were stained for $40 \mathrm{~min}$ at $37^{\circ} \mathrm{C}$. Analysis of the mean lipid area was performed using Image J software (Rasband, W.S., ImageJ, National Institutes of Health, Bethesda, MD, USA, http://imagej.nih.gov/ij/, 1997-2012), and five pictures were analyzed for each experiment.

Triglyceride measurement was done following the kit manufacturer's protocol.

\section{Measurement of cytokines and insulin}

IL1B, IL18, and CCL20 in adipocytes and insulin levels in PANC-1 cell culture medium were determined by ELISA following the manufacturer's instructions. Data were normalized to the total cell number used for the experiments.

Published by Bioscientifica Ltd. 


\section{Statistical analysis}

Statistical analyses were performed using Prism 4.0 software (GraphPad Software, San Diego, CA, USA). Treatment efficacy and differences between multiple treatments were determined by ANOVA test and post hoc Bonferroni's correction. An unpaired $t$-test was used for analyzing a comparison of the two groups. A value of $P<0.05$ was considered statistically significant. All data are shown as mean \pm s.e.M. or mean \pm s.D.

\section{Results}

\section{Gene profiling and pathways analysis}

To analyze the role of BPA in modulating the canonical endocrine function involved in metabolic homeostasis at the molecular level, we first evaluated the pattern modifications that were primed by estrogen and associated with metabolism. To this end, we performed transcriptional profiling by exposing human in vitrodifferentiated mature adipocytes obtained from male non-obese, prepubertal children to $\mathrm{E}_{2}$. Adipocytes were treated with $1 \mathrm{nM} \mathrm{E}_{2}$, a concentration that was previously reported as the minimum dose needed to achieve BPAsimilar effects on adiponectin suppression in adipose tissue from human breast explants (Hugo et al. 2008). This concentration is also known to activate in vitro ERs (Li et al. 2012).

Preadipocytes from five samples were in vitro differentiated in mature adipocytes as described in the Materials and methods section, and ORO staining was used as a control of the correct differentiation. Cell differentiation was induced for $72 \mathrm{~h}$ to allow us to observe the morphological change in the fibroblast-like phenotype. 24 hours after differentiation, the cells exhibited the typical morphological characteristics of mature adipocytes, having accumulated red lipid droplets in the cytoplasm (Supplementary Figure 1, see section on supplementary data given at the end of this article).

Microarray analysis was performed using a Human Gene 1.0 ST arrays that interrogates 28869 well-annotated genes. Differentiated adipocytes were treated for $24 \mathrm{~h}$ with $\mathrm{E}_{2}$ before processing. Vehicle-only treated cells were used as a control.

Gene-level expression profiling was detected by linear model statistics using an empirical Bayes method to moderate the standard errors. To evaluate transcriptional modifications, $\mathrm{E}_{2}$-treated cells were compared to control cells. To identify differentially expressed genes, an absolute $\log _{2}$-fold change $\geq \pm 1$ and a $P$ value of $\leq 0.05$ were applied as cutoffs. Following this method, a total of 29 differentially expressed genes were selected from the $\mathrm{E}_{2}$-treated cells.

This small number is probably a result of the high background noise related to the number and kind of samples. In fact, it should be remembered that a relatively small sample size shows a high degree of variability. This variability can be the result of combined influences, both genetic and nutritional.

A complete list of differentially expressed genes in the $\mathrm{E}_{2}$-treated cells is reported in Supplementary Table 1, see section on supplementary data given at the end of this article. These genes were functionally classified through an IPA Core Analysis (IPA 7.0, Ingenuity System) that associates molecules with known biological functions and diseases. The link between a category and the associated molecules is defined by a $P$ value. Significant $P$ values indicate that the molecules-function association is not the result of random chance.

The analysis showed that most of these genes were associated with diseases and biofunctions that were mainly related to inflammation, carbohydrate and lipid metabolism, cell signaling, and metabolic diseases with $P$ values that ranged from $2.84 \times 10^{-6}$ to $1.66 \times 10^{-3}$ (Fig. 1A). This was expected, as it is well known that estrogens are associated with metabolism regulation and inflammation.

To find functional relationships among the genes that are specifically involved in metabolic disorders, we performed an IPA pathway analysis. The resulting pathway highlighted several closely linked genes that are related to obesity and metabolic diseases. In particular, we found some pro-inflammatory cytokines, such as chemokine (C-C motif) ligand 13 (CCL13), chemokine (C-C motif) ligand 20 (CCL20), interleukin 18 (IL18), and IL1 beta (IL1B), associated in the pathway. Overproduction of these molecules within the adipose tissue has been associated with the development of insulin resistance (Odegaard et al. 2007). We also found associated in the pathway CD36 molecule (CD36) and fatty acid binding protein 4 (FABP4), two molecules that are involved in lipid binding and transport, and proprotein convertase subtilisin/kexin type 1 (PCSK1), which is involved in the active production of insulin (Fig. 1B and C). The results of the associated genes in this pathway were very interesting, because they could play a key role in metabolic disorders depending on how they are expressed.

Published by Bioscientifica Ltd. 


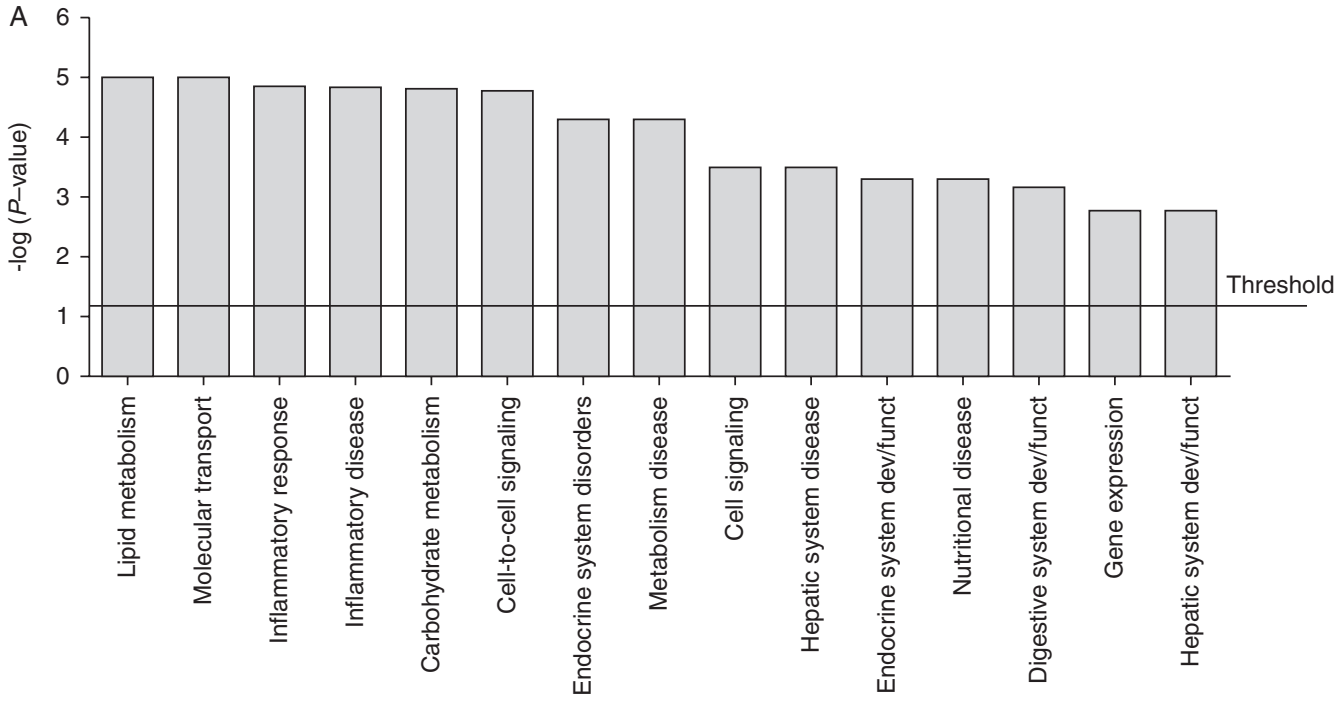

B

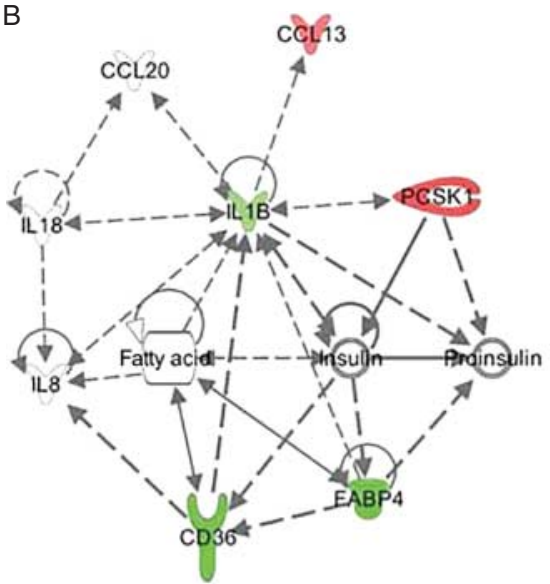

C

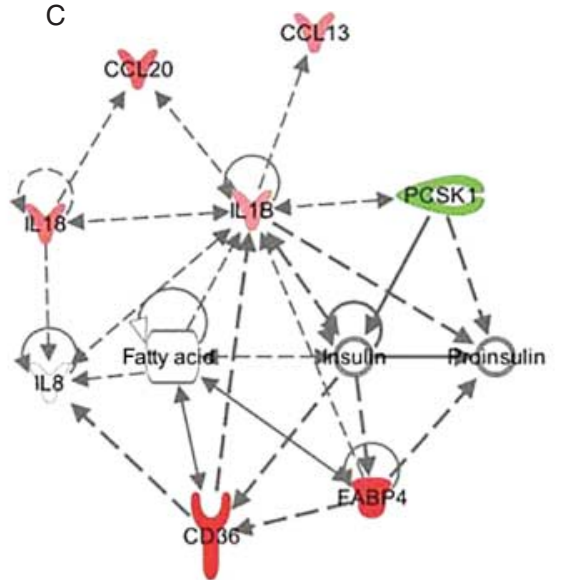

Symbols legend

(Y) Cytokine

$\checkmark$ Chemical

Group/complex/other

Peptidase

Transmembrane receptor

7 Transporter

- Direct interaction

- Indirect interaction
Figure 1

IPA functional analysis. (A) Functional classification showed that most of the genes are associated with diseases and biofunctions that are mainly related to inflammation, carbohydrate and lipid metabolism, cell signaling, and metabolic diseases. A class is considered significant when the $P$ value is above the threshold. (B and C) Functional relationship between

\section{Validation of gene expression and BPA effects on selected genes}

To independently validate the expression of the genes highlighted in the pathway, we used qRT-PCR. Furthermore, to investigate whether BPA could have an estrogenlike or an estrogen-antagonist action in adipocytes, we checked their expression after $\mathrm{E}_{2}$ or BPA treatment.

To this end, a preliminary experiment was performed to identify the most effective BPA concentration for the modulation of gene expression. Preadipocytes from eight non-obese, prepubertal children were in vitro differentiated into mature adipocytes as described deregulated genes related to metabolic disorders and their relative qRTPCR expression after $E_{2}$ (B) or BPA (C) treatment. Red indicates up-regulated genes, whereas green indicates down-regulated genes. A full colour version of this figure is available at http://dx.doi.org/10.1530/JME-14-0282.

above and were treated in a time-course analysis (12, 24, and $48 \mathrm{~h}$ ) with different environmental doses of BPA exposure (1, 10, and $100 \mathrm{nM}$ ) (Hugo et al. 2008). BPA concentrations were chosen by taking into account previous studies that described the concentrations that were able to affect metabolic homeostasis (Hugo et al. 2008), the BPA ranges found in adult and fetal serum (Welshons et al. 2006), and the range of BPA concentrations detected by our group in children's urine (Nicolucci et al. 2013).

Gene modulation exerted by BPA in adipose tissue was assessed by measuring the expression of

Published by Bioscientifica Ltd 


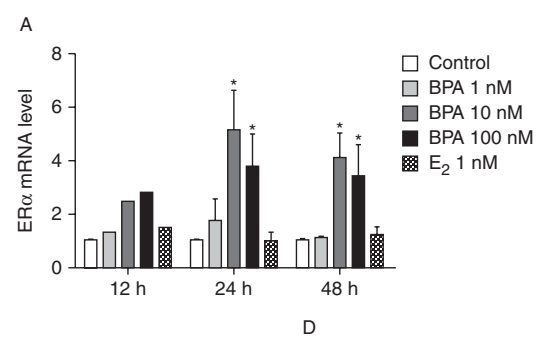

B

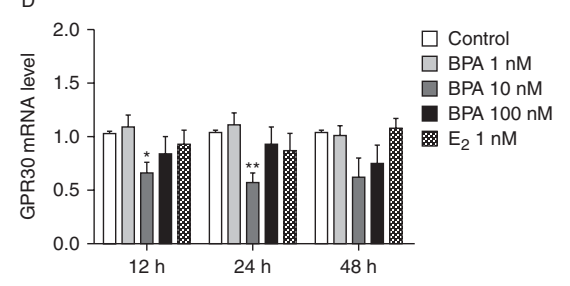

Figure 2

BPA gene modulation in adipose tissue. The effect of different BPA concentrations $(1,10$, or $100 \mathrm{nM})$ at different times $(12,24$, or $48 \mathrm{~h})$ on the expression of (A) ER $\alpha$, (B) ER $\beta$, (C) ERR $\gamma$, (D) GPR30, and (E) leptin in mature adipocytes derived from preadipocytes from children. $E_{2}$ treatment (1 nM)

estrogen-responsive receptors that are known to interact with BPA and are expressed in human adipose tissue, including: estrogen receptor alpha (ESR1, ER $\alpha$ ), estrogen receptor beta (ESR2, ER $\beta)$, estrogen-related receptor gamma (ESRRG, ERR $\gamma$ ) and $G$ protein-coupled receptor 30 (GPER, GPR30). Their expression supports the suggestion that adipose tissue is potentially BPA responsive (Hugo et al. 2008, Vom Saal et al. 2012).

Figure 2A shows that ER $\alpha$ is up-regulated by low doses of BPA stimulation. Specifically, 10 and $100 \mathrm{nM} \mathrm{BPA}$ are the most effective doses for modulating ER $\alpha$ gene expression. No difference was observed after $E_{2}$ treatment.

No changes were found in ER $\beta$ mRNA levels after BPA exposure (Fig. 2B). Figure 2C shows that ERR $\gamma$ mRNA levels are up-regulated after $10 \mathrm{nM}$ BPA or $\mathrm{E}_{2}$ stimulation. Both $\mathrm{ER} \alpha$ and ERR $\gamma$ expression data show a typical trend of inverted $U$ dose response being tightly linked to BPA exposure that has also been described by other studies (Boucher et al. 2014, Liang et al. 2014, Vandenberg 2014). The expression of GPR30 specifically decreased after the $10 \mathrm{nM}$ BPA treatment (Fig. 2D) and supports the dual activity of BPA in the signaling pathway, because it can act through either a classical or a non-classical estrogenic pathway (Sharma et al. 2013).

The modulation of ER $\alpha$ expression indicates that BPA might directly alter the estrogen signaling pathways with antagonist activity, whereas ERR $\gamma$ expression appeared similar in both the BPA and $\mathrm{E}_{2}$ treatments.

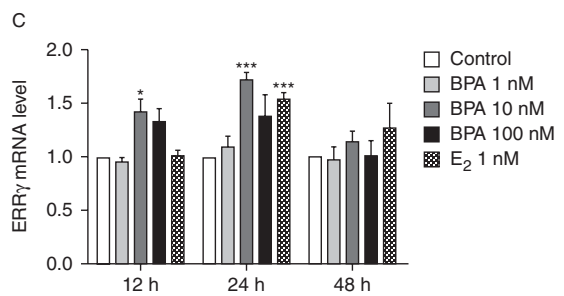

$\mathrm{E}$

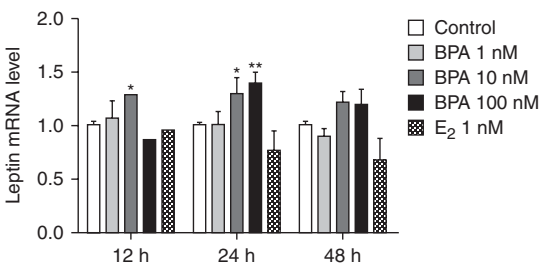

was used to compare BPA effects to the effects of canonical hormones. Data represent mean fold change \pm s.D. relative to the untreated cells $* P<0.05$, $* * P<0.01, * * * P<0.001$ as compared to the control.

The obesogenic activity of BPA was further demonstrated by the expression of leptin, one of the most important adipose-derived hormones, which plays a key role in regulating energy homeostasis, appetite, and metabolism and acts directly in the hypothalamus (Brennan \& Mantzoros 2006). Figure 2E indicates that Leptin mRNA levels in mature adipocytes from children were up-regulated following the 10 and $100 \mathrm{nM}$ BPA treatments as compared to the control cells.

These results allowed us to choose $10 \mathrm{nM}$ as the BPA concentration and $24 \mathrm{~h}$ as the time treatment for the subsequent experiments. Thus, qRT-PCR was used to compare gene expression levels in adipocytes after $\mathrm{E}_{2}$ or BPA treatment. As shown in Table 3, qRT-PCR mostly confirmed the expression trend that was detected by microarray analysis after $\mathrm{E}_{2}$ treatment. Surprisingly, BPA treatment resulted in an opposite expression for most of the genes (Table 3 and Fig. 3B), which suggests that the accumulation of BPA in the adipose tissue could affect the normal endocrine functions of mature adipocytes.

\section{BPA promotes inflammation and lipid accumulation}

To test whether the gene expression changes caused by BPA in adipocytes could have a physiological and/or functional significance, further experiments were performed to see if the biochemical responses were consistent with our hypothesis.

qRT-PCRs showed that BPA induces the expression of the pro-inflammatory genes CCL20, IL18, and IL1B.

Published by Bioscientifica Ltd 
Table 3 Differentially deregulated genes associated with metabolic disorders in $E_{2}$-treated adipocytes and qPCR expression after $E_{2}$ or BPA treatment. $\mathrm{qPCR}$ values are expressed as mean \pm s.D. as reported in the columns

\begin{tabular}{|c|c|c|c|}
\hline \multirow[b]{2}{*}{ Gene } & \multirow[b]{2}{*}{ Description } & \multicolumn{2}{|c|}{$E_{2}$} \\
\hline & & Array fold change ${ }^{a}$ & $\mathrm{qPCR}^{\mathrm{b}}$ \\
\hline CCL13 & $\begin{array}{l}\text { Chemokine (C-C motif) } \\
\text { ligand } 13\end{array}$ & 1.48 & $1.14 \pm 0.5$ \\
\hline CCL2O & $\begin{array}{l}\text { Chemokine (C-C motif) } \\
\text { ligand } 20\end{array}$ & -2 & $2.118 \pm 0.7$ \\
\hline$C D 36$ & CD36 molecule & -2.488 & $-1.35 \pm 0.4$ \\
\hline FABP4 & $\begin{array}{l}\text { Fatty acid binding } \\
\text { protein } 4\end{array}$ & -2.401 & $-1.04 \pm 0.2$ \\
\hline IL18 & Interleukin 18 & 1.586 & $-1.31 \pm 0.2$ \\
\hline$I L 1 B$ & Interleukin 1 beta & -1.376 & $-1.7 \pm 0.2$ \\
\hline IL8 & Interleukin 8 & -2 & $1.28 \pm 0.8$ \\
\hline PCSK1 & $\begin{array}{l}\text { Proprotein convertase } \\
\text { subtilisin/kexin type } 1\end{array}$ & 1.848 & $1.80 \pm 0.2$ \\
\hline
\end{tabular}

\begin{tabular}{c}
\hline BPA \\
\hline $\mathrm{qPCR}^{\mathrm{b}}$ \\
\hline $1.957 \pm 0.8$ \\
$2.086 \pm 0.7$ \\
$2.047 \pm 0.6$ \\
$1.306 \pm 0.3$ \\
$1.575 \pm 0.5$ \\
$2.17 \pm 0.7$ \\
$-1.562 \pm 0.5$ \\
$-1.366 \pm 0.2$
\end{tabular}

Association with metabolic disorders

Hashimoto et al. (2006)

Duffaut et al. (2009) and Villaret et al. (2010)

Hajri et al. (2002), Pravenec et al. (2003) and Rac et al. (2007)

Hardaway \& Podgorski (2013)

Banerjee \& Saxena (2012)

Ouchi et al. (2011) and Esser et al. (2013)

Samaras et al. (2010) and Banerjee \& Saxena (2012)

Creemers et al. (2012) and Martin et al. (2013)

aPerformed on five samples.

${ }^{b}$ Performed on eight samples.

Therefore, we checked the secretion of deregulated cytokines IL1B, IL18, and CCL20 in adipocyte culture medium after a $24 \mathrm{~h}$ treatment with $10 \mathrm{nM}$ BPA. As shown in Fig. 3, all of these inflammatory cytokines were released at higher levels in the medium with BPA-treated cells. In particular, the amount of secreted IL1B was about three times higher than it was in control cells: $14.4 \mathrm{pg} / 10^{6}$ cells vs $4.17 \mathrm{pg} / 10^{6}$ cells; the amount of secreted IL18 was about two times higher than it was in control cells: $20.16 \mathrm{pg} / 10^{6}$ cells vs $10.98 \mathrm{pg} / 10^{6}$ cells; and the amount of secreted CCL20 was about six times higher than it was in control cells: $18.74 \mathrm{pg} / 10^{6}$ cells vs $3.25 \mathrm{pg} / 10^{6}$ cells. These results confirm that BPA promotes inflammation in mature adipocytes.

We then assessed if the BPA-mediated dysregulation of CD36 and FABP4 - two genes involved in lipid binding and transport - could affect lipid metabolism by evaluating the cytoplasmic lipid accumulation. To this end, mature adipocytes were treated with 1,10 , and $100 \mathrm{nM} \mathrm{BPA}$, and accumulation of lipid droplets were analyzed by determining the mean lipid area size of fat depots in mature adipocytes (Fig. 4A and B). The results showed a close correlation between BPA exposure and adipocyte hypertrophy, which is also correlated to BPA concentration (Fig. 4), with a mean lipid area that was significantly higher in the 1 and $10 \mathrm{nM} \mathrm{BPA-exposed} \mathrm{cells} \mathrm{(36.35} \mathrm{and} 52.47 \mu \mathrm{m}^{2}$ respectively) as compared to the control cells $\left(28.65 \mu \mathrm{m}^{2}\right)$. Similar results were obtained when measuring the cellular triglyceride content, which was significantly increased after the BPA treatment (Fig. 4C).

\section{BPA regulates insulin production}

We also tested whether the PCSK1 down-regulation that was observed after BPA treatment could result in a physiological outcome.

PCSK1 encodes for pro-protein convertase (PC1/3), an enzyme that is involved in pro-insulin cleavage and in subsequent insulin activation (Turpeinen et al. 2013).

Previous studies in rodents indicated that BPA directly affects pancreatic $\beta$-cell functions (Alonso-Magdalena et al. 2010, Wei et al. 2011), and a recent paper has demonstrated in a rat insulinoma cell line that BPA affects pancreatic function on insulin production by decreasing insulin production and secretion (Lin et al. 2013).

To evaluate whether BPA is linked to insulin production via PCSK1 gene down-regulation, BPA effects were investigated in PANC-1 cells, which are widely used as a human model of pancreatic cells because of their ability to secrete insulin in response to high amounts of glucose in the culture medium (Hamil et al. 2008).

As shown in Fig. 5A, PANC-1 cells treated with $10 \mathrm{nM}$ BPA secreted a total amount of active insulin that was significantly lower $\left(\sim 0.30 \mu \mathrm{g}\right.$ insulin $/ 10^{6}$ cells $)$ than untreated cells $\left(\sim 0.45 \mu \mathrm{g}\right.$ insulin $/ 10^{6}$ cells).

Furthermore, this reduction is related to a decrease in the corresponding PCSK1 mRNA after BPA exposure (Fig. 5B), which is in agreement with the results reported in Table 3.

It might be possible that BPA, by down-regulating the expression of PCSK1, could determine a reduction of the corresponding protein level (PC1/3) that in turn could be

Published by Bioscientifica Ltd 

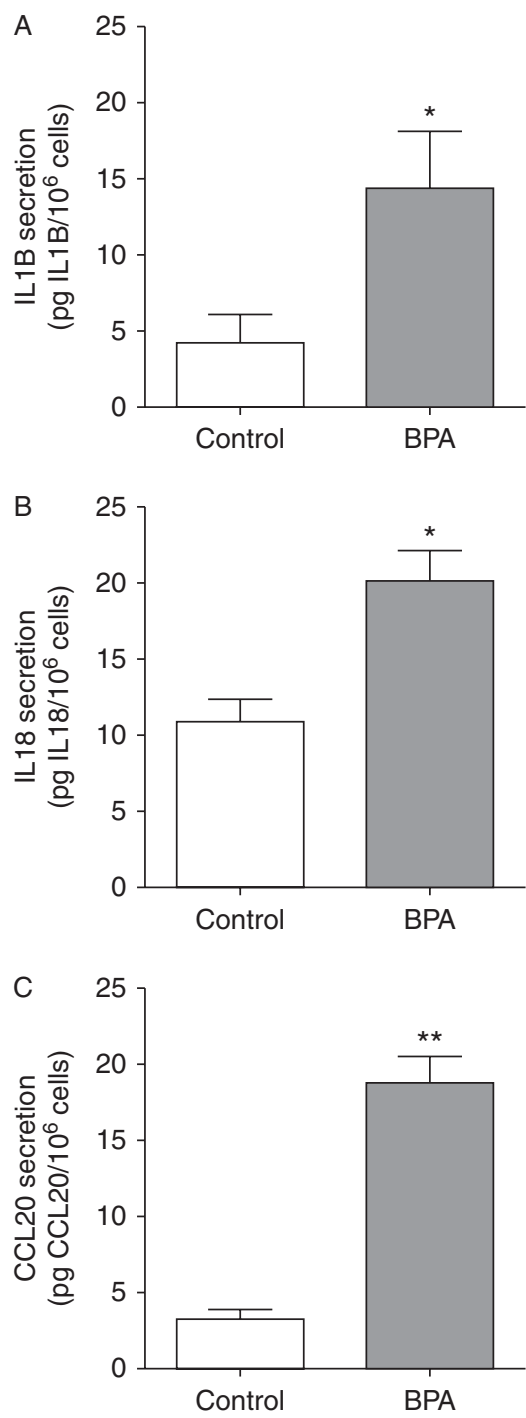

Figure 3

Cytokine secretion. IL1B (A), IL18 (B), and CCL20 (C) secretion in culture medium after BPA treatment ( $10 \mathrm{nM})$ for $24 \mathrm{~h}$, as determined by ELISA. Data are expressed as means \pm s.E.M. of three independent experiments. $* P<0.05, * * P<0.01$ as compared to the control.

insufficient for cleaving pro-insulin and for generating active insulin.

\section{Discussion}

It is well known that BPA, acting as an endocrine disruptor, influences the endocrine system by competing with endogenous hormones, and its action is more harmful during development.

This study describes the molecular effects induced by in vitro BPA exposure on human primary adipocytes obtained from children.
The molecular effects by which BPA exerts its disrupting effects in adipose tissue during childhood are currently stimulating great interest in the scientific community (Bhandari et al. 2013, Eng et al. 2013, Harley et al. 2013). Most of the published studies analyze the effects of BPA on adipogenesis in murine 3T3-L1 cells or in human cell cultures obtained from adult adipose tissue (Masuno et al. 2005, Hugo et al. 2008, Valentino et al. 2013). A recent paper described the effects of BPA on adipogenesis using adipose cells from children as a model system (Wang et al. 2013).

In this study, we investigated how environmentally relevant doses of BPA affect the endocrine function of mature adipocytes differentiated in vitro and obtained from subcutaneous adipose tissue of non-obese, prepubescent male children. Sex was selected on the basis of our previous study, which showed that obese male children have higher BPA urinary levels than females (Nicolucci et al. 2013). Prepubescent children were selected because they are not influenced by relevant sex hormonal regulation. Non-obese children were chosen in order to eliminate any experimental bias resulting from the dysregulation of endocrine functions often found in overweight subjects.

To this end, we first analyzed transcriptional modifications in adipocytes exposed to estrogen, focusing our attention on molecules associated with metabolism. Statistical data analysis identified a small number of differentially expressed genes, due to the high sample noise related to the small size and high variability of the human samples. Deregulated genes were functionally characterized by IPA analysis, which specifically identified carbohydrate, lipid, and endocrine metabolic pathways as the main functional categories to which these genes belong. A further pathway analysis of the genes associated with metabolic disorders highlighted a functional pathway in which a small group of genes are interconnected. These genes are involved in adipose tissue inflammation, obesity, and metabolic diseases.

It is known that estrogens regulate cellular metabolism by programming gene expression in adipocytes and that they are implicated in metabolic disorder restoration. A lack of estrogens increases fat mass and impairs glucose tolerance and insulin resistance (Vom Saal et al. 2012).

To investigate whether BPA could mimic estrogen activity or antagonize $\mathrm{E}_{2}$ function, we analyzed if BPA could have disrupting effects on the molecules highlighted in the pathway. To this end, we first checked the most suitable BPA concentration for inducing gene expression by testing the induction of the estrogen

Published by Bioscientifica Ltd 

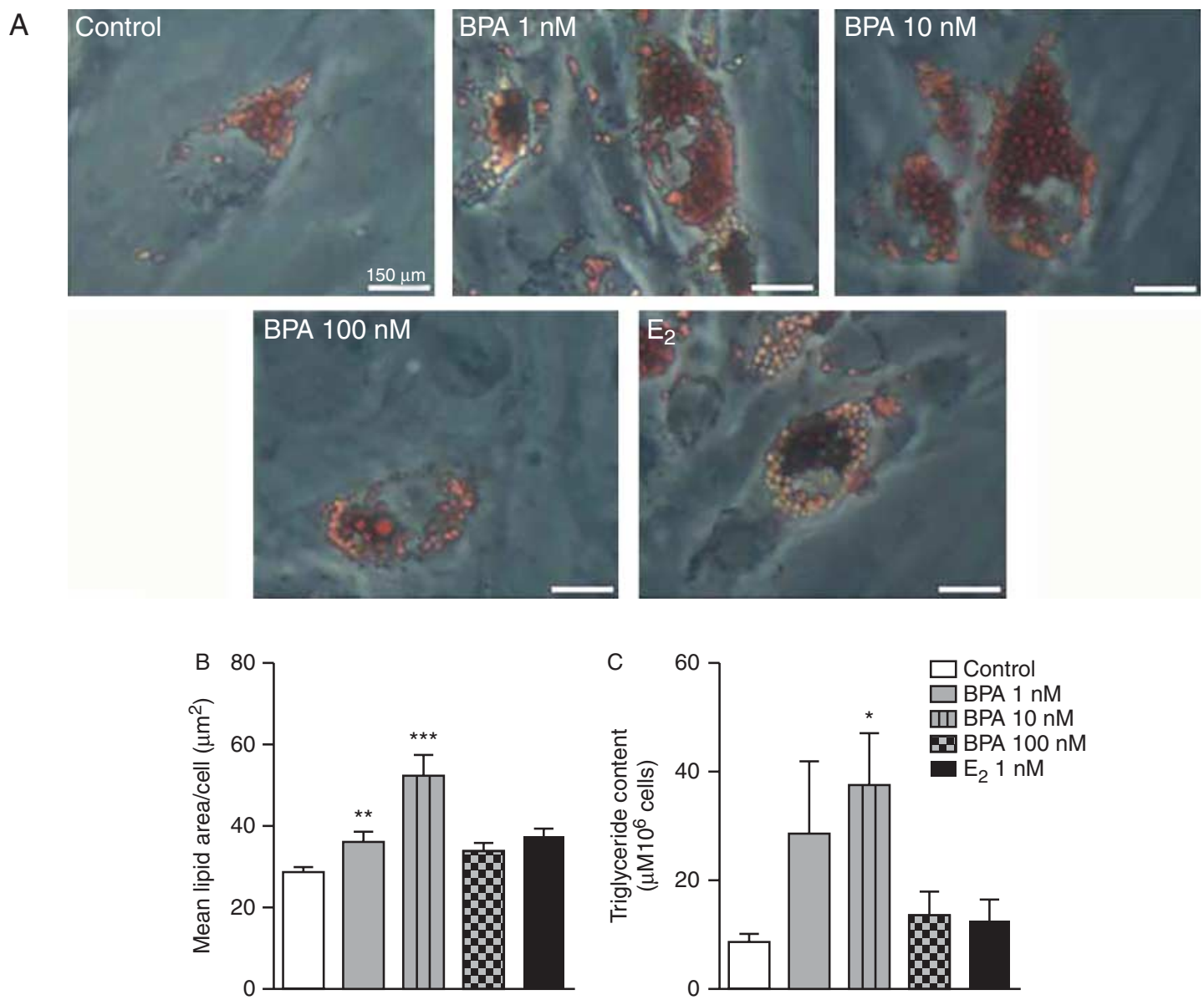

\section{Figure 4}

Lipid accumulation. (A) Mature adipocytes untreated or treated with 1, 10, or $100 \mathrm{nM}$ BPA for $24 \mathrm{~h}$ stained with oil red $\mathrm{O}$ ( $\times 400$ magnification).

(B) Mean lipid area per cell after ORO staining. (C) Cellular triglyceride content. $E_{2}$ treatment (1 $\left.\mathrm{nM}\right)$ was used to compare BPA effects. Data are expressed as means \pm S.E.M. of three independent experiments. ${ }^{\star} P<0.05$, $* * P<0.01, * * * P<0.001$ as compared to untreated cells. A full colour version of this figure is available at http://dx.doi.org/10.1530/JME-14-0282. responsive receptors $E R \alpha, E R \beta$, and $E R R \gamma$, which are known to be expressed in human adipose tissue and to interact with BPA. Low doses of BPA modulated the abundance of the ER $\alpha$ transcript, whereas no changes in ER $\beta$ mRNA levels were found. This was not surprising, given that BPA activity varies depending on specific estrogen receptor expression and on the distribution of those receptors within tissues. Specifically, it has been reported that in adipose tissue, ER $\beta$ is less expressed than $\mathrm{ER} \alpha$ (Hugo et al. 2008).

Overexpression of ERR $\gamma$ confirms the high binding affinity of BPA for ERR $\gamma$ (Takayanagi et al. 2006, Okada et al. 2008). ERR $\gamma$, a constitutive activator of transcription, is able to modulate the estrogen-signaling pathway not by binding directly to $\mathrm{E}_{2}$, but by controlling the transcription of essential genes that regulate metabolic processes (Liu et al. 2007, Giguere 2008).

The fact that ERR $\gamma$ expression also increased after $E_{2}$ treatment must not be considered misleading. Indeed, similar expression does not indicate that this corresponds to similar mechanisms; instead, it suggests that BPA may exert its action through non-classical estrogen receptors, which results in independent effects (Hugo et al. 2008, Tohme et al. 2014). The high BPA accumulation in adipose tissue also suggests that it acts as an endocrine disruptor by increasing the abundance of ERR $\gamma$ transcripts while also affecting the regulation of metabolic pathways.

More interesting is the modulation of GP30 expression, because GP30 reflects how BPA acts through the noncanonical estrogenic pathway. GPR30 is a seven-

Published by Bioscientifica Ltd 

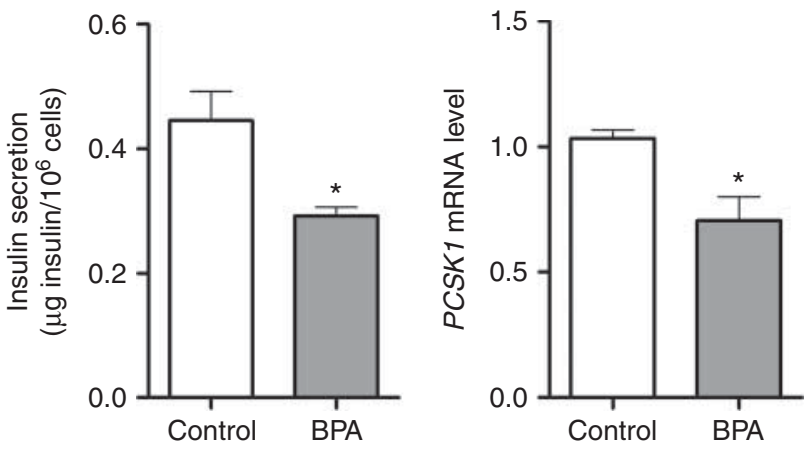

Figure 5

BPA affects active insulin secretion. (A) Active insulin secreted in culture medium after BPA treatment of PANC-1 cells. Data are expressed as means \pm s.E.M. of three independent experiments. (B) PCSK1 mRNA expression in PANC-1 cells. Data are expressed as means \pm s.D. of three independent experiments. ${ }^{\star} P<0.05$ as compared to the control.

transmembrane estrogen receptor that increases the activity of adenylate cyclase as a second messenger. The subsequent increase in intracellular cAMP regulates phosphatidylinositol 3-kinase/protein kinase B (PI3K/Akt) signaling, a well-known regulator of glucose metabolism. BPA has been reported to elicit rapid responses by binding GPR30 and activating alternative non-genomic estrogen signaling pathways (Thomas \& Dong 2006). In particular, the downregulation obtained with $10 \mathrm{nM} \mathrm{BPA}$ is a novelty and leads us to hypothesize that BPA could influence PI3K/Akt signaling. The data of this study agrees well with previous studies that show that GPR30 knockout mice displayed impaired glucose tolerance, reduced body growth, and increased body weight (Martensson et al. 2009, Ford et al. 2011). Our data can be considered additional evidence that BPA at low doses may act not only via ER $\alpha$ but also by activating non-canonical ER pathways.

The up-regulation of leptin mRNA levels is very intriguing and agrees with the results of a previous study (Angle et al. 2013). Leptin production by adipocytes is proportional to their fat content; leptin serum levels are higher in obese subjects, and are directly correlated to adipose mass and adipocyte contents (Fried et al. 2000, Yang \& Barouch 2007). These considerations clearly indicate that BPA treatment may have an obesogenic effect.

The BPA doses used in this study showed that the well-established non-monotonic dose response related to the BPA action, which regulates endocrine pathways, exhibits a $U$ or an inverted U shape (Vom Saal et al. 2012, Boucher et al. 2014, Liang et al. 2014, Vandenberg 2014). This suggests that BPA concentrations in the typical range of environmental human exposure induce non-linear effects during childhood.
IPA pathway analysis allowed us to identify the altered expression of the genes involved in adipose tissue inflammation as well as some key genes involved in obesity and metabolic diseases.

CCL2O encodes for a cytokine involved in immunoregulatory and inflammatory processes as well in metabolism. Elevated serum CCL13 and CCL20 concentrations are found in overweight subjects during chronic inflammation. Furthermore, CCL2O is directly correlated with BMI (Hashimoto et al. 2006, Duffaut et al. 2009, Villaret et al. 2010).

IL18 and IL1B are important regulators of inflammatory responses. As pro-inflammatory factors that are also secreted from adipocytes, interleukins contribute to the chronic low-grade inflammatory state of adipose depots that is often observed in obesity and type 2 diabetes (Samaras et al. 2010, Banerjee \& Saxena 2012). Their expression and secretion in adipose tissue increase in metabolic disorders (Esser et al. 2013). Their increased production could also explain the link between obesity and metabolic diseases (Samaras et al. 2010, Ouchi et al. 2011).

CD36 is an integral membrane protein that binds oxidized lipoproteins and lipids (Endemann et al. 1993). It plays a key role in fatty acid and glucose metabolism, and its dysregulation is involved in glucose intolerance and diabetes (Hajri et al. 2002, Rac et al. 2007).

Similarly, FABP4 is produced in adipocytes, and it is involved in fatty acid uptake and metabolism; it is also an important contributor to metabolic dysfunction in obesity-induced chronic inflammation and dyslipidemia (Hardaway \& Podgorski 2013).

PCSK1 encodes pro-protein convertase subtilisin/ kexin type 1 (PC1/3), a pro-insulin-processing enzyme that regulates insulin biosynthesis. PC1/3 cleaves proinsulin to produce active insulin. Mutations of or deficiencies in PC1/3 are thought to cause early obesity (Creemers et al. 2012, Turpeinen et al. 2013).

To investigate whether BPA can mimic estrogen activity or antagonize $\mathrm{E}_{2}$ function, we first analyzed the expression of the genes by qRT-PCR. The results showed that most of these genes, which were previously associated with metabolic disorders, had opposite expressions in the two treatments. Adipose tissue represents the major source of the pro-inflammatory cytokines and chemokines observed in obesity, and chronic low-grade inflammation is generally associated with obesity. It is known that CD36 null mice display enhanced insulin responsiveness, which is associated with a reduction in fat deposition (Hajri et al. 2002). IL1B has recently been associated with insulin resistance and type 2 diabetes (Tack et al. 2012), and its

Published by Bioscientifica Ltd. 
inhibition reduces hyperglycemic inflammation in obese mice (Owyang et al. 2010).

The expression of FABP4 and PCSK1 also suggests an obesogenic role for BPA, because elevated FABP4 plasma levels are associated with metabolic syndrome (Xu et al. 2007), whereas a deficiency of PCSK1 leads to serious multi-hormonal disorder marked by early-onset obesity (Jackson et al. 1997).

To assess the disrupting effects of BPA, we investigated the physiological outcomes of BPA treatment for all genes for which the microarray expression was confirmed by qRT-PCR, which had opposite expression from that seen in the $\mathrm{E}_{2}$ and BPA treatments.

The induction of inflammation was assessed by measuring IL1B, IL18, and CCL20 secretion. BPA-treated mature adipocytes show increased secretion of all of these chemokines (Fig. 3). In agreement with the recent finding that BPA up-regulates inflammatory pathways in 3T3-L1 cells and in adult human subcutaneous adipocytes (Valentino et al. 2013), our data corroborated the hypothesis that the strong relationship between BPA and the inflammatory state of adipose depots that occur in late obesity and in metabolic syndrome can be induced during childhood.

Inflammation and lipid metabolism are closely associated (Iyer et al. 2010), so we tested whether up-regulation of CD36 and FABP4 induced adipose depot expansion and triglyceride accumulation. The results showed a significant increase in intracellular lipid droplets and in triglyceride concentration. Up-regulation of $F A B P 4$ and $C D 36$ indicated that BPA affects adipocyte lipid storage, which leads to cellular hypertrophy. A possible consequence could be a metabolic dysregulation that results in a resistin secretion increase as well as in a decrease in adiponectin production in vitro (C Menale, A Grandone, C Nicolucci, G Cirillo, S Crispi, A Di Sessa, S Rossi, D G Mita, L Perrone, E M Del Giudice, N Diano, unpublished observations). In addition, this up-regulation might impair glucose metabolism, as confirmed by preliminary experiments performed in a mouse model (C Menale, personal communication). This result led us to hypothesize that BPA might increase the oxidative stress of hypertrophic adipocytes and might contribute to the inflammation and dysregulation of free fatty acid efflux (Zha \& Zhou 2012).

Finally, we tested whether PCSK1 down-regulation by BPA affects active insulin secretion in the human PANC-1 cell line. The results showed that BPA effectively impairs active insulin production and that its decrease is related to PCSK1 mRNA down-regulation. This novel view regarding BPA activity indicates that PCSK1 could be considered a new player that is involved in the endocrine disruption that is caused by BPA, because it participates in metabolic disorders in childhood by playing a key role in the deregulation of insulin biosynthesis, which in turn, considering the physiological context, could affect the pancreas-adipose tissue crosstalk. In vivo preliminary observations by $\mathrm{C}$ Menale (personal communication) indicate that BPA exposure in the mouse impairs glucose tolerance by compromising insulin production and/or secretion. The putative key role of PCSK1 dysregulation needs to be further investigated in vivo.

Taken together, our results suggest that the modulation of gene expression by BPA leads to fatty acid metabolism dysfunction, pro-inflammatory cytokine production, and insulin secretion; all of these are conditions that can be ascribed to metabolic disorders.

In conclusion, this study shows that BPA at environmental doses in mature adipocytes from children acts by modulating gene expression, which leads to molecular changes that promote metabolic disorders. Considering that the persistence of BPA in the environment and in the human body, specifically in adipose tissue, might be an important risk factor, the results of this study provide a strong argument for further research in vitro and in vivo on the contribution of BPA exposure to the development of obesity and diabetes.

\section{Supplementary data}

This is linked to the online version of the paper at http://dx.doi.org/10.1530/ JME-14-0282.

\section{Declaration of interest}

The authors declare that there is no conflict of interest that could be perceived as prejudicing the impartiality of the research reported.

\section{Funding}

This work was supported by the Italian Ministry of Health (grant number RF-2009-1536185: 'Food and Environmental Safety: The Problem of the Endocrine Disruptors', coordinated by D G M).

\section{Author contribution statement}

S C, C M, D G M, and N D developed the conceptual framework for the study and coordinated the data discussion; $\mathrm{S} C$ and $\mathrm{C} M$ conceived and designed the experiments and wrote the paper; $C M, M T P$, and G C performed the experiments; R A C analyzed the microarray data; C M, L M, and E M D G analyzed the data; A P provided the subcutaneous adipose tissue.

\section{Acknowledgements}

We thank the Interuniversity Consortium INBB for supporting $\mathrm{Dr} C$ Menale and Dr M T Piccolo with fellowships; Dr Rosarita Tatè for her help with the

Published by Bioscientifica Ltd. 
microscopy analysis; the Institute of Genetics and Biophysics-Integrated Microscopy Facility; and Dr Maria Rosaria Chiummo for her assistance with revising the manuscript.

\section{References}

Alonso-Magdalena P, Vieira E, Soriano S, Menes L, Burks D, Quesada I \& Nadal A 2010 Bisphenol A exposure during pregnancy disrupts glucose homeostasis in mothers and adult male offspring. Environmental Health Perspectives 118 1243-1250. (doi:10.1289/ehp.1001993)

Alonso-Magdalena P, Ropero AB, Soriano S, Garcia-Arevalo M, Ripoll C, Fuentes E, Quesada I \& Nadal A 2012 Bisphenol-A acts as a potent estrogen via non-classical estrogen triggered pathways. Molecular and Cellular Endocrinology 355 201-207. (doi:10.1016/j.mce.2011.12.012)

Angle BM, Do RP, Ponzi D, Stahlhut RW, Drury BE, Nagel SC, Welshons WV, Besch-Williford CL, Palanza P, Parmigiani S et al. 2013 Metabolic disruption in male mice due to fetal exposure to low but not high doses of bisphenol A (BPA): evidence for effects on body weight, food intake, adipocytes, leptin, adiponectin, insulin and glucose regulation. Reproductive Toxicology 42 256-268. (doi:10.1016/j.reprotox.2013.07.017)

Banerjee M \& Saxena M 2012 Interleukin-1 (IL-1) family of cytokines: role in type 2 diabetes. Clinica Chimica Acta 413 1163-1170. (doi:10.1016/j.cca.2012.03.021)

Bhandari R, Xiao J \& Shankar A 2013 Urinary bisphenol A and obesity in U.S. children. American Journal of Epidemiology 177 1263-1270. (doi:10.1093/aje/kws391)

Boucher JG, Boudreau A \& Atlas E 2014 Bisphenol A induces differentiation of human preadipocytes in the absence of glucocorticoid and is inhibited by an estrogen-receptor antagonist. Nutrition \& Diabetes 4 e102. (doi:10.1038/nutd.2013.43)

Brennan AM \& Mantzoros CS 2006 Drug Insight: the role of leptin in human physiology and pathophysiology - emerging clinical applications. Nature Clinical Practice. Endocrinology \& Metabolism 2 318-327. (doi:10.1038/ncpendmet0196)

Creemers JW, Choquet H, Stijnen P, Vatin V, Pigeyre M, Beckers S, Meulemans S, Than ME, Yengo L, Tauber M et al. 2012 Heterozygous mutations causing partial prohormone convertase 1 deficiency contribute to human obesity. Diabetes 61 383-390. (doi:10.2337/ db11-0305)

Crispi S 2013 Transcriptional profiling of endometriosis tissues identifies genes related to organogenesis defects. Journal of Cellular Physiology $\mathbf{2 2 8}$ 1927-1934. (doi:10.1002/jcp.24358)

Crispi S, Calogero RA, Santini M, Mellone P, Vincenzi B, Citro G, Vicidomini G, Fasano S, Meccariello R, Cobellis G et al. 2009 Global gene expression profiling of human pleural mesotheliomas: identification of matrix metalloproteinase 14 (MMP-14) as potential tumour target. PLoS One 4 e7016. (doi:10.1371/journal.pone.0007016)

Delclos KB, Camacho L, Lewis SM, Vanlandingham MM, Latendresse JR, Olson GR, Davis KJ, Patton RE, Gamboa da Costa G, Woodling KA et al. 2014 Toxicity evaluation of bisphenol A administered by gavage to Sprague Dawley rats from gestation day 6 through postnatal day 90 . Toxicological Sciences 139 174-197. (doi:10.1093/toxsci/kfu022)

Duffaut C, Zakaroff-Girard A, Bourlier V, Decaunes P, Maumus M, Chiotasso P, Sengenes C, Lafontan M, Galitzky J \& Bouloumie A 2009 Interplay between human adipocytes and $\mathrm{T}$ lymphocytes in obesity CCL20 as an adipochemokine and T lymphocytes as lipogenic modulators. Arteriosclerosis, Thrombosis, and Vascular Biology 29 1608-1614. (doi:10.1161/ATVBAHA.109.192583)

Endemann G, Stanton LW, Madden KS, Bryant CM, White RT \& Protter AA 1993 CD36 is a receptor for oxidized low density lipoprotein. Journal of Biological Chemistry 268 11811-11816.

Eng DS, Lee JM, Gebremariam A, Meeker JD, Peterson K \& Padmanabhan V 2013 Bisphenol A and chronic disease risk factors in US children. Pediatrics 132 e637-e645. (doi:10.1542/peds.2013-0106)
Esser N, L'Homme L, De Roover A, Kohnen L, Scheen AJ, Moutschen M, Piette J, Legrand-Poels S \& Paquot N 2013 Obesity phenotype is related to NLRP3 inflammasome activity and immunological profile of visceral adipose tissue. Diabetologia 56 2487-2497. (doi:10.1007/ s00125-013-3023-9)

Ford J, Hajibeigi A, Long M, Hahner L, Gore C, Hsieh JT, Clegg D, Zerwekh J \& Oz OK 2011 GPR30 deficiency causes increased bone mass, mineralization, and growth plate proliferative activity in male mice. Journal of Bone and Mineral Research 26 298-307. (doi:10.1002/ jbmr.209)

Fried SK, Ricci MR, Russell CD \& Laferrere B 2000 Regulation of leptin production in humans. Journal of Nutrition 130 3127S-3131S.

Giguere V 2008 Transcriptional control of energy homeostasis by the estrogen-related receptors. Endocrine Reviews 29 677-696. (doi:10.1210/ er.2008-0017)

Hajri T, Han XX, Bonen A \& Abumrad NA 2002 Defective fatty acid uptake modulates insulin responsiveness and metabolic responses to diet in CD36-null mice. Journal of Clinical Investigation 109 1381-1389. (doi:10.1172/JCI0214596)

Halden RU 2010 Plastics and health risks. Annual Review of Public Health 31 179-194. (doi:10.1146/annurev.publhealth.012809.103714)

Hamil L, Benghuzzi H \& Tucci M 2008 Evaluation of insulin secretion by pancreatic cells in response to increasing amounts of glucose. Biomedical Sciences Instrumentation 44 441-446.

Hardaway AL \& Podgorski I 2013 IL-1 $\beta$, RAGE and FABP4: targeting the dynamic trio in metabolic inflammation and related pathologies. Future Medicinal Chemistry 5 1089-1108. (doi:10.4155/fmc.13.90)

Harley KG, Aguilar Schall R, Chevrier J, Tyler K, Aguirre H, Bradman A, Holland NT, Lustig RH, Calafat AM \& Eskenazi B 2013 Prenatal and postnatal bisphenol A exposure and body mass index in childhood in the CHAMACOS cohort. Environmental Health Perspectives 121 514-520, 520e511-516. (doi:10.1289/ehp.1306866)

Hashimoto I, Wada J, Hida A, Baba M, Miyatake N, Eguchi J, Shikata K \& Makino H 2006 Elevated serum monocyte chemoattractant protein-4 and chronic inflammation in overweight subjects. Obesity 14 799-811. (doi:10.1038/oby.2006.93)

Hugo ER, Brandebourg TD, Woo JG, Loftus J, Alexander JW \& Ben-Jonathan N 2008 Bisphenol A at environmentally relevant doses inhibits adiponectin release from human adipose tissue explants and adipocytes. Environmental Health Perspectives 116 1642-1647. (doi:10.1289/ehp.11537)

Iyer A, Fairlie DP, Prins JB, Hammock BD \& Brown L 2010 Inflammatory lipid mediators in adipocyte function and obesity. Nature Reviews. Endocrinology 6 71-82. (doi:10.1038/nrendo.2009.264)

Jackson RS, Creemers JW, Ohagi S, Raffin-Sanson ML, Sanders L, Montague CT, Hutton JC \& O'Rahilly S 1997 Obesity and impaired prohormone processing associated with mutations in the human prohormone convertase 1 gene. Nature Genetics 16 303-306. (doi:10.1038/ng0797-303)

Kang JH, Kondo F \& Katayama Y 2006 Human exposure to bisphenol A. Toxicology 226 79-89. (doi:10.1016/j.tox.2006.06.009)

Kuri-Harcuch W \& Green H 1978 Adipose conversion of 3T3 cells depends on a serum factor. PNAS 75 6107-6109. (doi:10.1073/pnas.75.12.6107)

Lakind JS, Goodman M \& Mattison DR 2014 Bisphenol A and indicators of obesity, glucose metabolism/type 2 diabetes and cardiovascular disease: a systematic review of epidemiologic research. Critical Reviews in Toxicology 44 121-150. (doi:10.3109/10408444.2013.860075)

Lee HA, Kim YJ, Lee H, Gwak HS, Park EA, Cho SJ, Kim HS, Ha EH \& Park H 2013 Effect of urinary bisphenol a on androgenic hormones and insulin resistance in preadolescent girls: a pilot study from the Ewha birth \& growth cohort. International Journal of Environmental Research and Public Health 10 5737-5749. (doi:10.3390/ijerph10115737)

Li Y, Burns KA, Arao Y, Luh CJ \& Korach KS 2012 Differential estrogenic actions of endocrine-disrupting chemicals bisphenol A, bisphenol AF, and zearalenone through estrogen receptor $\alpha$ and $\beta$ in vitro. Environmental Health Perspectives 120 1029-1035. (doi:10.1289/ehp.1104689) 
Liang Q, Gao X, Chen Y, Hong K \& Wang HS 2014 Cellular mechanism of the nonmonotonic dose response of bisphenol $\mathrm{A}$ in rat cardiac myocytes. Environmental Health Perspectives 122 601-608.

Lin Y, Sun X, Qiu L, Wei J, Huang Q, Fang C, Ye T, Kang M, Shen H \& Dong S 2013 Exposure to bisphenol A induces dysfunction of insulin secretion and apoptosis through the damage of mitochondria in rat insulinoma (INS-1) cells. Cell Death \& Disease 4 e460. (doi:10.1038/ cddis.2012.206)

Liu X, Matsushima A, Okada H, Tokunaga T, Isozaki K \& Shimohigashi Y 2007 Receptor binding characteristics of the endocrine disruptor bisphenol A for the human nuclear estrogen-related receptor $\gamma$. Chief and corroborative hydrogen bonds of the bisphenol A phenol-hydroxyl group with Arg316 and Glu275 residues. FEBS Journal 274 6340-6351. (doi:10.1111/j.1742-4658.2007.06152.x)

Martensson UE, Salehi SA, Windahl S, Gomez MF, Sward K, DaszkiewiczNilsson J, Wendt A, Andersson N, Hellstrand P, Grande PO et al. 2009 Deletion of the $\mathrm{G}$ protein-coupled receptor 30 impairs glucose tolerance, reduces bone growth, increases blood pressure, and eliminates estradiol-stimulated insulin release in female mice. Endocrinology 150 687-698. (doi:10.1210/en.2008-0623)

Martin MG, Lindberg I, Solorzano-Vargas RS, Wang J, Avitzur Y, Bandsma R, Sokollik C, Lawrence S, Pickett LA, Chen Z et al. 2013 Congenital proprotein convertase $1 / 3$ deficiency causes malabsorptive diarrhea and other endocrinopathies in a pediatric cohort. Gastroenterology 145 138-148. (doi:10.1053/j.gastro.2013.03.048)

Masuno H, Kidani T, Sekiya K, Sakayama K, Shiosaka T, Yamamoto H \& Honda K 2002 Bisphenol A in combination with insulin can accelerate the conversion of 3T3-L1 fibroblasts to adipocytes. Journal of Lipid Research 43 676-684.

Masuno H, Iwanami J, Kidani T, Sakayama K \& Honda K 2005 Bisphenol a accelerates terminal differentiation of 3T3-L1 cells into adipocytes through the phosphatidylinositol 3-kinase pathway. Toxicological Sciences 84 319-327. (doi:10.1093/toxsci/kfi088)

Nicolucci C, Rossi S, Menale C, del Giudice EM, Perrone L, Gallo P, Mita DG \& Diano N 2013 A high selective and sensitive liquid chromatographytandem mass spectrometry method for quantization of BPA urinary levels in children. Analytical and Bioanalytical Chemistry $\mathbf{4 0 5}$ 9139-9148. (doi:10.1007/s00216-013-7342-y)

Odegaard JI, Ricardo-Gonzalez RR, Goforth MH, Morel CR, Subramanian V, Mukundan L, Red Eagle A, Vats D, Brombacher F, Ferrante AW et al. 2007 Macrophage-specific PPAR $\gamma$ controls alternative activation and improves insulin resistance. Nature 447 1116-1120. (doi:10.1038/ nature05894)

Ohlstein J, Strong AL, McLachlan JA, Gimble JM, Burow ME \& Bunnell BA 2014 Bisphenol A enhances adipogenic differentiation of human adipose stromal/stem cells. Journal of Molecular Endocrinology $\mathbf{5 3}$ 345-353. (doi:10.1530/JME-14-0052)

Okada H, Tokunaga T, Liu X, Takayanagi S, Matsushima A \& Shimohigashi Y 2008 Direct evidence revealing structural elements essential for the high binding ability of bisphenol A to human estrogen-related receptor- $\gamma$. Environmental Health Perspectives 116 32-38. (doi:10.1289/ ehp.10587)

Ouchi N, Parker JL, Lugus JJ \& Walsh K 2011 Adipokines in inflammation and metabolic disease. Nature Reviews. Immunology 11 85-97. (doi:10.1038/nri2921)

Owyang AM, Maedler K, Gross L, Yin J, Esposito L, Shu L, Jadhav J, Domsgen E, Bergemann J, Lee $S$ et al. 2010 XOMA 052, an anti-IL-1 $\beta$ monoclonal antibody, improves glucose control and $\beta$-cell function in the diet-induced obesity mouse model. Endocrinology 151 2515-2527. (doi:10.1210/en.2009-1124)

Pravenec M, Landa V, Zidek V, Musilova A, Kazdova I, Oi N, Wang J, St Lezin E \& Kurtz TW 2003 Transgenic expression of CD36 in the spontaneously hypertensive rat is associated with amelioration of metabolic disturbances but has no effect on hypertension. Physiological Research $\mathbf{5 2}$ 681-688.

http://jme.endocrinology-journals.org DOI: $10.1530 / J M E-14-0282$

(C) 2015 Society for Endocrinology Printed in Great Britain
Rac ME, Safranow K \& Poncyljusz W 2007 Molecular basis of human CD36 gene mutations. Molecular Medicine 13 288-296. (doi:10.2119/200600088.Rac)

Rochester JR 2013 Bisphenol A and human health: a review of the literature. Reproductive Toxicology 42 132-155. (doi:10.1016/j.reprotox. 2013.08.008)

Sakurai K, Kawazuma M, Adachi T, Harigaya T, Saito Y, Hashimoto N \& Mori C 2004 Bisphenol A affects glucose transport in mouse 3T3-F442A adipocytes. British Journal of Pharmacology 141 209-214. (doi:10.1038/ sj.bjp.0705520)

Samaras K, Botelho NK, Chisholm DJ \& Lord RV 2010 Subcutaneous and visceral adipose tissue gene expression of serum adipokines that predict type 2 diabetes. Obesity 18 884-889. (doi:10.1038/oby.2009.443)

Sharma G, Hu CL, Brigman JL, Zhu G, Hathaway HJ \& Prossnitz ER 2013 GPER deficiency in male mice results in insulin resistance, dyslipidemia, and a proinflammatory state. Endocrinology 154 4136-4145. (doi:10.1210/en.2013-1357)

Singh S \& Li SS 2012 Bisphenol A and phthalates exhibit similar toxicogenomics and health effects. Gene 494 85-91. (doi:10.1016/ j.gene.2011.11.035)

Smyth GK 2004 Linear models and empirical bayes methods for assessing differential expression in microarray experiments. Statistical Applications in Genetics and Molecular Biology 3 1-25. (doi:10.2202/15446115.1027)

Tack CJ, Stienstra R, Joosten LA \& Netea MG 2012 Inflammation links excess fat to insulin resistance: the role of the interleukin-1 family. Immunological Reviews 249 239-252. (doi:10.1111/j.1600-065X.2012. 01145.x)

Takayanagi S, Tokunaga T, Liu X, Okada H, Matsushima A \& Shimohigashi Y 2006 Endocrine disruptor bisphenol A strongly binds to human estrogen-related receptor gamma (ERR $\gamma)$ with high constitutive activity. Toxicology Letters 167 95-105. (doi:10.1016/j.toxlet. 2006.08.012)

Thomas P \& Dong J 2006 Binding and activation of the seventransmembrane estrogen receptor GPR30 by environmental estrogens: a potential novel mechanism of endocrine disruption. Journal of Steroid Biochemistry and Molecular Biology 102 175-179. (doi:10.1016/j.jsbmb. 2006.09.017)

Tohme M, Prud'homme SM, Boulahtouf A, Samarut E, Brunet F, Bernard L, Bourguet W, Gibert Y, Balaguer P \& Laudet V 2014 Estrogen-related receptor $\gamma$ is an in vivo receptor of bisphenol A. FASEB Journal $\mathbf{2 8}$ 3124-3133. (doi:10.1096/fj.13-240465)

Trasande L, Attina TM \& Blustein J 2012 Association between urinary bisphenol A concentration and obesity prevalence in children and adolescents. Journal of American Medical Association 308 1113-1121. (doi:10.1001/2012.jama.11461)

Turpeinen H, Ortutay Z \& Pesu M 2013 Genetics of the first seven proprotein convertase enzymes in health and disease. Current Genomics 14 453-467. (doi:10.2174/1389202911314050010)

Valentino R, D'Esposito V, Passaretti F, Liotti A, Cabaro S, Longo M, Perruolo G, Oriente F, Beguinot F \& Formisano P 2013 Bisphenol-A impairs insulin action and up-regulates inflammatory pathways in human subcutaneous adipocytes and 3T3-L1 cells. PLoS ONE 8 e82099. (doi:10.1371/journal.pone.0082099)

Vandenberg LN 2014 Non-monotonic dose responses in studies of endocrine disrupting chemicals: bisphenol a as a case study. Dose-Response 12 259-276. (doi:10.2203/dose-response.13-020)

Villaret A, Galitzky J, Decaunes P, Esteve D, Marques MA, Sengenes C, Chiotasso P, Tchkonia T, Lafontan M, Kirkland JL et al. 2010 Adipose tissue endothelial cells from obese human subjects: differences among depots in angiogenic, metabolic, and inflammatory gene expression and cellular senescence. Diabetes 59 2755-2763. (doi:10.2337/db10-0398)

Vom Saal FS, Nagel SC, Coe BL, Angle BM \& Taylor JA 2012 The estrogenic endocrine disrupting chemical bisphenol A (BPA) and obesity.

Published by Bioscientifica Ltd. 
Molecular and Cellular Endocrinology 354 74-84. (doi:10.1016/j.mce. 2012.01.001)

Wang J, Sun B, Hou M, Pan X \& Li X 2013 The environmental obesogen bisphenol A promotes adipogenesis by increasing the amount of 11ß-hydroxysteroid dehydrogenase type 1 in the adipose tissue of children. International Journal of Obesity 37 999-1005. (doi:10.1038/ ijo.2012.173)

Wei J, Lin Y, Li Y, Ying C, Chen J, Song L, Zhou Z, Lv Z, Xia W, Chen $X$ et al. 2011 Perinatal exposure to bisphenol A at reference dose predisposes offspring to metabolic syndrome in adult rats on a high-fat diet. Endocrinology 152 3049-3061. (doi:10.1210/ en.2011-0045)

Welshons WV, Nagel SC \& vom Saal FS 2006 Large effects from small exposures. III. Endocrine mechanisms mediating effects of bisphenol A at levels of human exposure. Endocrinology 147 S56-S69. (doi:10.1210/ en.2005-1159)

Westfall PH \& Young SS 1993 Resampling-Based Multiple Testing: Examples and Methods for p-Value Adjustment. New York, NY, USA: John Wiley \& Sons.

$\mathrm{Xu}$ A, Tso AW, Cheung BM, Wang Y, Wat NM, Fong CH, Yeung DC, Janus ED, Sham PC \& Lam KS 2007 Circulating adipocyte-fatty acid binding protein levels predict the development of the metabolic syndrome: a 5-year prospective study. Circulation 115 1537-1543. (doi:10.1161/CIRCULATIONAHA.106.647503)

Yang R \& Barouch LA 2007 Leptin signaling and obesity: cardiovascular consequences. Circulation Research 101 545-559. (doi:10.1161/ CIRCRESAHA.107.156596)

Zha BS \& Zhou H 2012 ER stress and lipid metabolism in adipocytes. Biochemistry Research International 2012 312943. (doi:10.1155/2012/312943)

Received in final form 18 March 2015

Accepted 1 April 2015
Published by Bioscientifica Ltd. 